\title{
KAJIAN TENTANG PENGARUH KEPADATAN LALU LINTAS TERHADAP KEBISINGAN YANG DITIMBULKAN KENDARAAN BERMOTOR
}

\author{
Dindin Syafrudin, Rulhendri \\ Program Studi Teknik Sipil, Universitas Ibn Khaldun Bogor \\ E-mail: dindin syafrudin@gmail.com
}

\begin{abstract}
ABSTRAK
Setiap kendaraan bermotor baik sepeda motor, mobil pribadi, penumpang umum, mobil pengangkut barang seperti truck yang bergardan 4 akan menimbulkan suara dengan tingkat kebisingan yang bervariatif. Suara yang timbul pada kendaraan dipengaruhi mesin dan model knalpot dari kendaraan yang bersangkutan. Tujuan penelitian ini adalah untuk memperoleh seberapa besar tingkat kebisingan yang ditimbulkan oleh kendaraan pada ruas jalan Ciawi-Puncak dan menganalisa apakah kebisingannya masih dibawah ambang baku tingkat kebisingan yang diizinkan. Berdasarkan pembahasan diatas bahwa peningkatan kepadatan sepeda motor, mobil angkutan pribadi, mobil angkutan umum dan mobil angkutan barang terhadap kebisingan yang di timbulkan, maka diperoleh hasil sebagai berikut. Kepadatan sepeda motor, mobil angkutan pribadi, mobil angkutan umum dan mobil angkutan barang memiliki pengaruh yang signifikan terhadap kebisingan, dari semua perhitungan analisis didapatkan persamaan terbesar pada penelitian hari ketiga titik kedua (Sound Level Meter 2), dengan kontribusi sebesar 23,70\%. Didapatkan perhitungan di bawah ini, $Y=63,080$ $+0,036 \times 1+0,139 \times 2-0,129 \times 3+0,943 \times 4$. Maksudnya jika tidak ada penurunan kepadatan sepeda motor maka tingkat kebisingan di SLM 2 adalah sebesar 63,080 dB $\mathrm{d}_{\mathrm{A}}$. Apabila terjadi penambahan peningkatan kepadatan sepeda motor sebesar $+1,118$ kend./jam dan penurunan kepadatan mobil angkutan umum -0,129 kend./jam. Kepadatan sepeda motor, mobil pribadi, mobil angkutan umum dan mobil angkutan barang juga memiliki pengaruh yang signifikan terhadap kebisingan didapatkan persamaan kedua terbesar terbesar pada penelitian hari ke empat dititik ke tiga dengan kontribusi sebesar 21,70\%. Didapatkan perhitungan persamaan di bawah ini, $Y=61,101+0,054 \times 1-0,067 \times 2+$ $0,052 \times 3-0,286 \times 4$. Maksud dari persamaan diatas adalah jika ada peningkatan kepadatan sepeda motor, mobil angkutan umum maka kebisingan di SLM 3 adalah sebesar 61,101 dBA. Jadi untuk penurunan kepadatan angkutan pribadi dan kepadatan mobil angkutan barang sebesar 0,353 kend./jam dan maka akan terjadi peningkatan kepadatan sepeda motor, peningkatan mobil angkutan umum sebesar 0,106 kend./jam.
\end{abstract}

Kata kunci: Sepeda motor; sound level meter; kebisingan.

\begin{abstract}
Every motorized vehicle, motorbike, private car, public passenger, goods transport vehicle such as truck with four wheels, will produce noise with varied noise level. The sound that arises in the vehicle is influenced by the engine and exhaust model of the vehicle in question. The purpose of this study is to obtain the level of noise caused by vehicles on the Ciawi-Puncak road section and analyze whether the noise is still below the permitted noise level threshold. Based on the discussion above that increasing the density of motorcycles, private transport cars, public transport cars and goods transport cars against the noise caused, the following results are obtained. The density of motorbikes, private transport cars, public transport cars and goods transport cars has a significant effect on noise, of all the analytical calculations found the greatest similarity in the research on the third day of the second point (Sound Level Meter 2), with a contribution of 23.70\%. Obtained the calculation below, $Y=63,080$ $+0,036 \times 1+0,139 \times 2-0,129 \times 3+0,943 \times 4$. That is if there is no reduction in motorcycle density, the noise level in SLM 2 is 63,080 dBA. If there is an increase in motorcycle density by $+1,118$ vehicles / hour and a decrease in the density of public transport cars $-0,129$ vehicles / hour. The density of motorcycles, private cars, public transport cars and freight vehicles also has a significant effect on noise. The second largest equation was found in the fourth day of research in the third point with a contribution of $21.70 \%$. Obtained the equation below, $Y=61.101+0.054 \times 1-0.067 \times 2+0.052 \times 3-$ $0.286 \times 4$. The purpose of the above equation is if there is an increase in motorcycle density, public transport cars, the noise in SLM 3 is $61,101 \mathrm{dBA}$. So to decrease the density of private transportation and the density of goods transport cars by 0.353 vehicles/hour and there will be an increase in motorcycle density, an increase in public transport cars by 0.106 vehicles / hour.
\end{abstract}

Keywords: Motorcycle; sound level meter; noise. 


\section{PENDAHULUAN}

Kondisi jalan mengalami perkembangan sesuai pertumbuhan kendaraan yang dilewati sebagai akibat pertumbuhan jumlah penduduk, pertumbuhan laju ekonomi dan jumlah kendaraan. Setiap kendaraan bermotor baik itu sepeda motor, mobil pribadi, penumpang umum, mobil pengangkut barang seperti truck yang bergardan 4 akan menimbulkan suara dengan tingkat kebisingan yang bervariatif. Suara yang timbul pada kendaraan dipengaruhi mesin dan model knalpot dari kendaraan yang bersangkutan. Teknisi otomotif telah berusaha meminimalisasi kebisingan dari kendaraan dengan penciptaan teknologi automotive yang lebih canggih akan tetapi kebisingan pada ruas jalan tertentu akan tetap terbentuk sebagai akibat dari akumulasi masing masing kebisingan kendaraan dan juga jarak bangunan di ruas jalan tersebut. Ruas jalan di kota kota di Indonesia pada umumnya tidak terlalu lebar, perkembangan peningkatan ruas jalan seperti pelebaran jalan tidak sebanding dengan perkembangan kendaraan (Syaiful, 2005; Syaiful, 2012; Syaiful, 2015).

Pada ruas jalan ciawi, pertumbuhan jumlah kendaraannya tidak sebanding dengan perkembangan ruas jalan untuk melayani kendaraan tersebut. Ruas jalan depan Rumah Sakit merupakan jalan dengan tingkat kepadatan tinggi terutama pada jam sibuk dengan berbagai jenis kendaraan yang melalui mulai dari kendaraan kecil sampai kendaraan penganngkut barang yang besar dimana jarak Rumah Sakit ke jalan diperkirakan kurang dari 50 ( Lima Puluh ) meter.

\section{Tujuan Penelitian}

Tujuan penelitian ini adalah untuk memperoleh seberapa besar tingkat kebisingan yang ditimbulkan oleh kendaraan pada ruas jalan Ciawi-Puncak dan menganalisa apakah kebisingannya masih dibawah ambang baku tingkat kebisingan yang diizinkan.

\section{Lalu lintas}

Hal yang sangat berperan dalam kebisingan pada ruas jalan adalah lalu lintas dimana diartikan sebagai kegiatan lalu lalang kendaraan baik itu kendaraan bermotor atau tidak, orang dan hewan di jalan.

Ini berarti komponen lalu lintas mencakup manusia sebagai pengguna jalan, kendaraan dan jalan yang saling berkaitan dan saling mempengaruhi satu sama lain (Syaiful and Elvira Y, 2017; Syaiful, 2017; Syaiful and Mikhael Yuliantino, 2017; Syaiful dan Zainal Abidin, 2017).

Kendaraan bermotor adalah kendaraan yang digerakkan oleh mesin seperti motor, mobil, bis dan truk sedangkan kendaraan tidak bermotor adalah kendaraan yang digerakkan oleh hewan seperti delman atau oleh manusia seperti becak. (Suwardjoko P. Warpani 2002)

\section{Berdasarkan daya dukungnya jalan di atur dalam berbagai kelas sebagai berikut:}

(1) Jalan kelas I, yaitu jalan arteri yang dilalui oleh kendaraan kendaraan bermotor termasuk muatan dengan ukuran lebar tidak lebih dari 2500 milimeter, ukuran panjang tidak lebih 18000 milimeter dan muatan sumbu terberat lebih besar dari 10 ton.

(2) Jalan kelas II, yaitu jalan arteri yang dilalui oleh kendaraan kendaraan bermotor termasuk muatan dengan ukuran lebar tidak lebih dari 2500 milimeter, ukuran panjang tidak lebih 18000 milimeter dan muatan sumbu terberat tidak lebih dari 10 ton.

(3) Jalan kelas III A, yaitu jalan arteri atau kolektor yang dapat dilalui kendaraan bermotor termasuk muatan dengan ukuran lebar tidak lebih dari 2500 milimeter, ukuran panjang tidak melebihi 18000 milimeter dan muatan sumbu terberat yang diizinkan 8 ton.

(4) Jalan kelas III B, yaitu jalan kolektor yang dapat dilalui kendaraan bermotor termasuk muatan dengan ukuran lebar tidak lebih dari 2500 milimeter, ukuran panjang tidak melebihi 12000 milimeter dan muatan sumbu terberat yang diizinkan 8 ton.

(5) Jalan kelas III C, yaitu jalan lokasi yang dapat dilalui kendaraan bermotor termasuk muatan dengan ukutan lebar tidak melebihi 2100 milimeter, ukuran panjang tidak melebihi 9000 milimeter dan muatan terberat yang diizinkan 8 ton.

Beberapa komponen yang mendukung lalu lintas diantaranya sebagai berikut :

(1) Kapasitas jalan

Nilai kapasitas di tunjukkan pada persamaan (1) sebagai berikut

$\mathrm{C}=\mathrm{CO} \times \mathrm{F} \mathrm{cw} \times \mathrm{FCsp} \times \mathrm{FCsp} \times \mathrm{FCcs}$ dengan :

C : kapasitas [smp/jam];

CO : kapasitas dasar untuk kondisi tertentu [smp/jam];

Fcw : faktor penyesuaian lebar jalur lalu lintas; 
FCsp : faktor penyesuaian pemisah arah;

FCsf : faktor penyesuaian hambatan samping;

FCcs : faktor penyesuaian ukuran kota.

(2) Volume kendaraan

Volume kendaraan adalah jumlah kendaraan yang melintasi satu titik pengamatan dalam satuan waktu. Volume kendaraan dapat kita ketahui dengan melakukan survey di lokasi Qtotal $=\mathrm{QMC}+\mathrm{QLv}+\mathrm{C} \mathrm{Hv}$

pengamatan. Hal lain yang mempengaruhi kebisingan dan berkaitan dengan kapasitas jalan adalah volume kendaraan, ditunjukkan pada persamaan (2) sebagai berikut :

Sedangkan Prosentase tiap jenis kendaraan kendaraan :

QMC \% = (QMC / Qtotal) $\times 100 \%$

QLV \% = (QLV / Qtotal) $\times 100 \%$

QHV\% $=($ QHV $/$ Qtotal $) \times 100 \%$

dengan : $\quad$ QMC $=$ Volume sepeda motor

$\mathrm{QLV}=$ Volume kendaraan ringan

$\mathrm{QHV}=$ Volume kendaraan berat

(3) Kepadatan kendaraan

Setiap kegiatan lalu lalang dari satu tempat ke tempat lain akan di tempuh dalam persatuan waktu, semakin cepat jalannya semakin pendek waktu yang di tempuh.

Kepadatan kendaraan bisa dihitung dengan persamaan (3)

$$
\mathrm{V}=\frac{\mathrm{S}}{\mathrm{T}}
$$

dengan : $\mathrm{V}=$ Kepadatan kendaraan $[\mathrm{km} / \mathrm{jam}]$

$$
\mathrm{S}=\text { Jarak yang ditempuh }[\mathrm{km}]
$$$$
\mathrm{T}=\text { Waktu tempuh [Jam] }
$$

Kepadatan rata rata dihitung dengan persamaan (4):

$$
V=\frac{(V M C X n M C)+(\mathrm{V} \mathrm{LvXnLV})+(\mathrm{VHvXnHV})}{n M C+L V+n H V}
$$

Begitu juga dengan kendaraan bermotor, jarak yang ditempuh dalam persatuan waktu oleh kendaraan disebut kepadatan kendaraan.

dengan :

$\mathrm{Vr} \quad=$ Kepadatan rata rata

$\mathrm{VMc}=$ Kepadatan sepeda motor

$\mathrm{nMc}=$ Jumlah sepeda motor yang melintasi yang dijadikan sampel pengamatan.

$\mathrm{VLV}=$ Kepadatan mobil ringan .

$n L v=$ Jumlah mobil ringan yang melintasi yang dijadikan sampel pengamatan.

$\mathrm{VHv}=$ Kepadatan mobil berat

$\mathrm{nHv}=$ Jumlah mobil berat yang melintasi yang di jadikan sampel pengamatan.

\section{(4) Kepadatan lalu lintas}

Kepadatan lalu lintas adalah jumlah kendaraan yang menempati panjang ruas jalan tertentu atau lajur.

$$
\begin{aligned}
& \mathrm{k}=\frac{N}{L} \\
& \text { Dengan: } \quad \mathrm{k}=\text { kepadatan... } \\
& \mathrm{N}=\text { Jumlah kendaraan } \\
& \mathrm{L}=\text { Panjang jalur. } \\
& \mathrm{k}=\frac{\text { Volume }}{\text { Kecepatan ruang rata rata }}
\end{aligned}
$$

Volume kendaraan $=$ jumlah kendaraan $/$ jam .

Kepadatan ruang rata rata $=$ jarak $/ \mathrm{jam} \quad[\mathrm{km} / \mathrm{jam}]$

Kebisingan

Kebisingan adalah suara/bunyi yang tidak diharapkan dimana timbul dari suatu kegiatan
Kepadatan lalu lintas dihitung dengan persamaan (5) dan (6) : dan mengganggu ketenangan, batas pendengaran telinga. Kebisingan adalah sebagai suara yang tidak diinginkan dari usaha 
atau kegiatan dalam tingkat dan waktu tertentu yang dapat menimbulkan gangguan kesehatan manusia dan kenyamanan lingkungan (Menteri Negara Lingkungan Hidup 1996)

Tipe kebisingan lingkungan seperti yang ditetapkan (KMNLH tahun 1996) adalah sebagai berikut :

(1) Jumlah kebisingan, adalah semua kebisingan di suatu tempat tertentu dalam satuan waktu tertentu.

(2) Kebisingan spesifik, adalah kebisingan di antara jumlah kebisingan yang dapat dengan jelas dibedakan untuk alasan alasan akustik. Seringkali sumber kebisingan dapat diindentifikasikan.

(3) Kebisingan residual, adalah kebisingan yang tertinggal sesudah penghapusan seluruh kebisingan spesifik dari jumlah kebisingan di suatu tempat tertentu dalam waktu tertentu.

(4) Kebisingan latar belakang, adalah semua kebisingan lainnya ketika memusatkan perhatian pada suatu kebisingan tertentu.

Menurut sifat dan spektrum bunyinya bising terbagi menjadi :

(1) Bising yang kontinyu dengan spectrum frekuensi yang luas.

Bising ini relative tetap dalam batas kurang lebih $5 \mathrm{~dB}$ untuk periode 0.5 detik berturut turut.

(2) Bising yang kontinyu dengan spectrum frekuensi yang sempit.

Bising ini juga relative tetap, akan tetapi hanya mempunyai frekuensi tertentu saja (pada frekuensi 500, 1000 dan $4000 \mathrm{~Hz}$ ) misalnya gergaji sekuler, katup gas.

(3) Bising terputus putus (intermitten).

(1) Basic Noise Level (BNL)

$L 10=42,2+10 \log Q^{d B_{(A)}}$

Dengan : $\quad$ L10 $=$ tingkat kebisingan dasar dalam 1 jam.

(2) Faktor koreksi BNL

$$
\mathrm{Q}=\text { arus lalu lintas. }
$$

Koreksi kepadatan rata rata $(\mathrm{V})$ dan prosentase kendaraan berat $(\mathrm{P})$ dengan :

$$
\mathrm{C} 1=33 \log \left(V+40+\frac{500}{V}+10 \log \left(1+\frac{5 p}{V}\right)-68,8^{d B_{(A)}}\right.
$$

(3) Koreksi terhadap gradien jalan (G) dinyatakan dengan :

$\mathrm{C} 2=0,3 \mathrm{G}^{d B_{(A)}}$

(4) Koreksi terhadap kondisi antara sumber bunyi dan penerima dinyatakan dengan :

(a) Kondisi lebih dari 50\% diperkeras atau tidak menyerap bunyi.

$c 3=-10 \log \left(\frac{\mathrm{d}^{I}}{13,5}\right) d B_{(A)}$ 
(b) Kondisi lebih dari 50\% penyerap bunyi alami (perumputan)

$$
c 3=-10 \log \left(\frac{\mathrm{d}^{t}}{13,5}\right) \mathrm{dB}+5.2 \log \left(\frac{3 \mathrm{~h}}{\mathrm{~d}+3,5}\right) d B_{(A)}
$$

Untuk $1<h((d+3,5) / 3)$

$$
c 3=-10 \log \left(\frac{\mathrm{d}^{r}}{13,5}\right) d B_{(A)}
$$

Untuk $h>((d+3,5) / 3)$

\section{Dimana :}

$\mathrm{h}=$ ketinggian titik penerima dari sumber bunyi $(\mathrm{m})$ $d^{\prime}=$ panjang garis pandang dari sumber bunyi ke penerima $(\mathrm{m})$

Tabel 1. Baku tingkat kebisingan $\mathrm{d}=$ jarak sumber bunyi dengan penerima (m)

Batasan nilai tingkat kebisingan untuk beberapa kawasan atau lingkungan dapat

\begin{tabular}{|c|c|c|}
\hline No - & $\begin{array}{l}\text { Peruntukan kawasan / lingkungan } \\
\text { kesehatan }\end{array}$ & Tigkat kebisingan \\
\hline 1 & $\begin{array}{ll} & \text { Peruntukan kawasan } \\
\text { a. } & \text { Perumahan dan pemukiman } \\
\text { b. } & \text { Perdagangan dan jasa } \\
\text { c. } & \text { Perkantoran dan perdagangan } \\
\text { d. } & \text { Ruang terbuka hijau } \\
\text { f. } & \text { Pdusti } \\
\text { g. } & \text { Remerintahan dan fasilitas umum } \\
\text { Rekreasi }\end{array}$ & $\begin{array}{l}55 \\
70 \\
65 \\
50 \\
70 \\
60 \\
70\end{array}$ \\
\hline 2 & $\begin{array}{l}\text { Lingkupkegiatan } \\
\text { a. } \\
\text { bumah sakit atau sejenisnya } \\
\text { c. }\end{array}$ & $\begin{array}{l}55 \\
55 \\
55\end{array}$ \\
\hline
\end{tabular}
dilihat sebagai berikut ;

\section{METODE PENELITIAN}

Waktu dan Tempat Penelitian

Waktu pengambilan data lapangan dilakukan selama empat hari hari, yaitu:

\section{Tempat Penelitian}

Tempat dan lokasi penelitian ini berada di depan Rumah Sakit yaitu jalan raya Bogor-Puncak ini termasuk jalan Nasional.

\section{Bahan}

Bahan yang digunakan dalam penelitian ini adalah berupa data form untuk mengambil data lalu lintas sepeda motor, mobil pribadi, angkutan umum dan angkutan barang serta data kebisingan yang di ambil dari hasil pengukuran alat kebisingan Sound Level Meter (SLM) yang di gunakan.

\section{Alat}

Untuk peralatan utama dan pendukung yang di gunakan dalam penelitian ini adalah sebagai berikut :

1) Sound Level Meter (SLM), sebagai alat utama untuk menghitung kebisingan yang terjadi pada tempat dan waktu tertentu. SLM yang di gunakan ini ada buah, yang diantaranya:

a) SLM 1, SLM Manual merk Krisbow, type KW06-291, b) SLM 2, SLM Manual merk Krisbow, type KW06-291, dan

c) SLM 3, SLM Outo merk Extech, type HD600.

2) Rol Meter, sebagai alat bantu pengukur jarak antara titik SLM dengan jalan dan bangunan tembok rumah sakit.

3) Kamera digital, untuk mendokumentasikan segala proses dalam penelitian berlangsung.

4) Tally atau alat bantu penghitung manual, sebagai alat bantu untuk menghitung jumlah kendaraan yang melintas di Jalan raya.

5) Laptop, sebagai alat bantu dalam pengambilan data dan mengolah data yang di peroleh dari lapangan selama penelitian berlangsung.

6) Alat tulis beserta petugas pencatat di lapangan, untuk membantu dalam mencatat segala hal yang di peroleh 
selama pengambilan data di lapangan berlangsung.

\section{Bagan alir penelitian}

Bagan alir penelitian disampaikan pada gambar 3 dibawah ini :

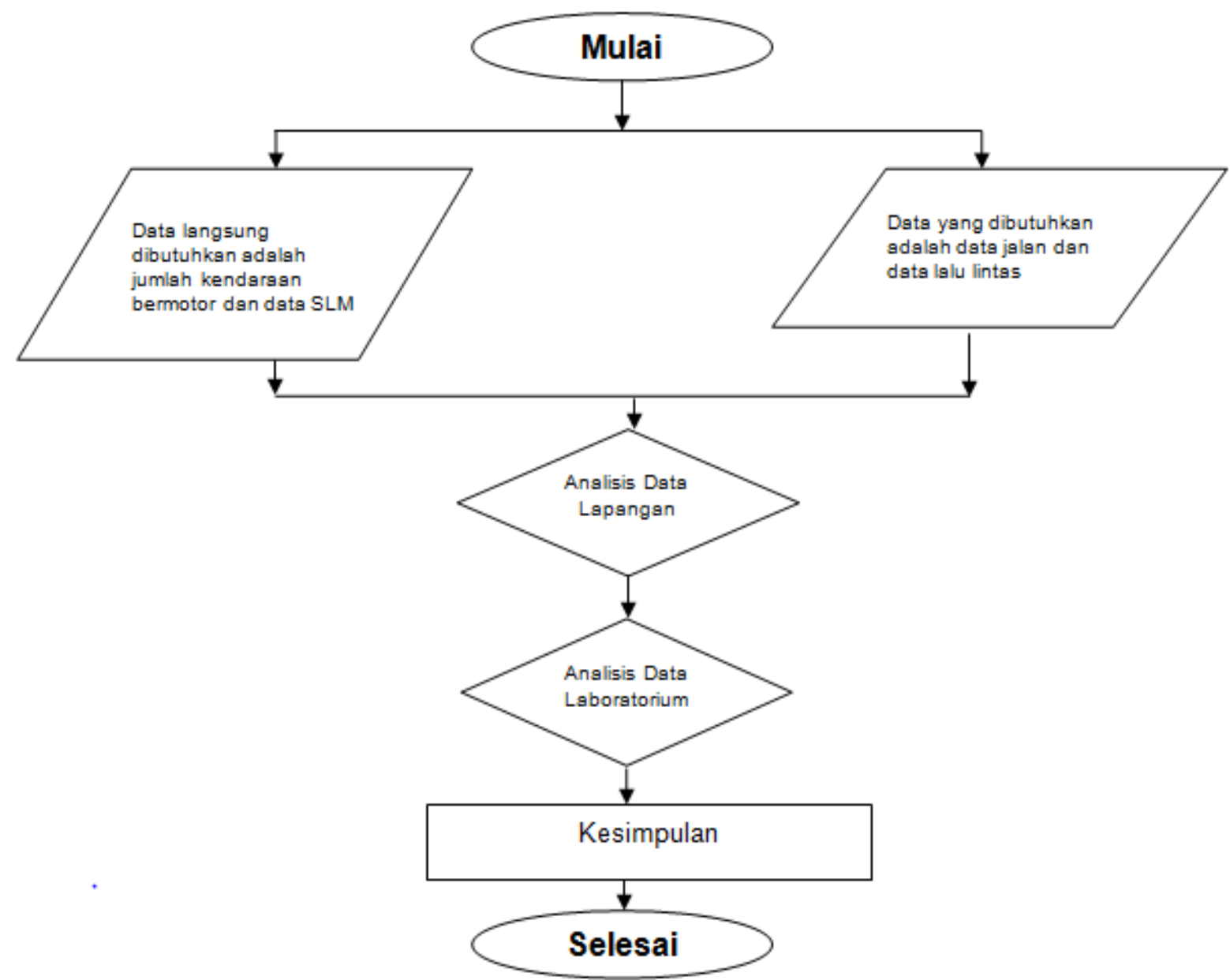

Gambar 3. Bagan alir Penelitian

\section{HASIL DAN BAHASAN}

\section{Hasil data lalu lintas}

Data hasil lalu lintas yang di hitung adalah data per 15 menit selama 12 jam dalam sehari. Data di ambil mulai dari pukul 6.00 sampai pukul 18.00. Data ini di ambil selama 4 hari, yaitu pada hari Rabu tanggal 26 Juni 2013, hari Kamis tanggal 27 Juni 2013, hari Sabtu tanggal 29 Juni 2013, dan hari Senin tanggal 1 Juli 2013.

Data hasil lalu lintas ini didapatkan dari hasil perhitungan Ekivalensi Mobil Penumpang (EMP). Penggunaan perhitungan ini dimaksudkan agar analisis lalu lintas mudah dilakukan faktor satuan mobil penumpang (SMP) masing-masing kendaraan bermotor menurut Manual Kapasitas Jalan Indonesia (MKJI 1997), untuk jalan perkotaan adalah sebagai berikut:
1) Kendaraan Berat (HV)
$=1,30$
2) Kendaraan Ringan (LV)
$=1,00$
3) Sepeda Motor (MC)
$=0,40$
4) Kendaraan tidak bermotor $=1,00$

Dalam

pelaksanaannya pengelompokan di bagi atas dua kelompok yaitu sepeda motor dan kendaraan ringan, dimana sepeda motor (MC) dengan nilai 0,40 dan kendaraan ringan yang termasuk (mobil pribadi, angkutan umum dan angkutan barang) dengan EMP 1,00.

\section{Jumlah Sepeda Motor (SPM)}

Berikut ini disajikan jumlah data sepeda motor baik dari arah Ciawi maupun dari arah Puncak yang menunjukkan tren meningkat.

\section{Jumlah Mobil Angkutan Pribadi (MAP)}

Berikut ini disajikan jumlah data mobil pribadi baik dari arah Ciawi maupun dari arah Puncak yang menunjukkan tren meningkat.

\section{Jumlah Mobil Angkutan Umum (MAU)}

Berikut ini disajikan jumlah data angkutan umum penumpang baik dari arah Ciawi maupun dari arah Puncak yang menunjukkan tren meningkat. 


\section{Jumlah Mobil Angkutan Barang (MAB)}

Berikut ini disajikan jumlah data sepeda motor baik dari arah Ciawi maupun dari arah Puncak yang menunjukkan tren meningkat. Hasil pengambilan data lengkap yaitu pada hari Kamis tanggal 27 Juni 2013, Sabtu tanggal 29 Juni 2013 dan Senin tanggal 01 Juli 2013, jumlah mobil pribadi, jumlah angkutan umum penumpang serta jumlah angkutan barang disajikan dalam bentuk lampiran.

Kepadatan sepeda motor (D) = Kepadatan $(\mathrm{U}) \times$ Volume $(\mathrm{Q})$

\section{Contoh perhitungan :}

Diketahui :

$$
\begin{array}{ll}
\text { Kepadatan } & =41,16 \mathrm{~km} / \mathrm{jam} \\
\text { Volume } & =1.768,00 \mathrm{kend} / \mathrm{jam} \\
\mathrm{D} & =17.768,29 \mathrm{kend} / \mathrm{km}
\end{array}
$$

\section{Kepadatan Sepeda Motor (SPM)}

Hasil kepadatan sepeda motor bahwa kepadatan sepeda motor mendekati normal.

\section{Kepadatan Mobil Angkutan Pribadi (MAP)}

Hasil kepadatan mobil pribadi bahwa kepadatan mobil pribadi normal.

\section{Kepadatan Mobil Angkutan Umum (MAU)}

Hasil kepadatan angkutan umum penumpang bahwa kepadatan angkutan umum penumpang mendekati stabil.

\section{Kepadatan Mobil Angkutan Barang (MAB)}

Hasil kepadatan angkutan barang

bahwa kepadatan angkutan barang sedikit yang mendekati jalur ini.

\section{Hasil Pengambilan Data SLM \\ Hasil Sound Level Meter jarak 0,00 dari tepi jalan raya}

Penyajian data SLM pada jarak $0,00 \mathrm{~m}$ dari tepi jalan raya menunjukkan data variatif kebisingan yang dihasilkan.

\section{Hasil Sound Level Meter jarak 3,00 dari tepi jalan raya}

Penyajian data SLM pada jarak $3,00 \mathrm{~m}$ dari tepi jalan raya menunjukkan data variatif kebisingan yang dihasilkan.

\section{Hasil Pengolahan Kepadatan \\ Berdasarkan panduan perhitungan} kepadatan dari Dinas Bina Marga Departemen Pekerjaan Umum Republik Indonesia bahwa pengambilan data dengan menggunakan kepadatan menggunakan rumus sebagai berikut :

Tabel 2. Interpretasi dari Nilai $r$

\begin{tabular}{|l|l|l|}
\hline No & \multicolumn{1}{|c|}{ r } & \multicolumn{1}{|c|}{ Interpretasi Nilai r } \\
\hline 1 & 0 & Tidak berkorelasi \\
2 & $0,01-0,20$ & Sangat rendah \\
3 & $0,21-0,40$ & Rendah \\
4 & $0,41-0,60$ & Agak rendah \\
5 & $0,61-0,80$ & Cukup tinggi \\
6 & $0,81-0,99$ & Tinggi \\
7 & 1 & Sangat tinggi \\
\hline
\end{tabular}

\section{Hasil Sound Level Meter jarak 16,00 dari jalan raya (disisi tembok bangunan rumah sakit).}

Penyajian data SLM pada jarak $16,00 \mathrm{~m}$ dari tepi jalan raya dan ditempatkan pada sisi tembok bangunan yang menunjukkan data variatif kebisingan.

\section{Pembahasan Kebisingan yang disebabkan Kendaraan Bermotor \\ Dari hasil pengolahan data menggunakan SPSS 17 dan dilakukan pemilihan data-data yang ada maka didapatkan sebagaimana terlampir. Namun untuk menunjukkan bahwa data yang direkomendasikan dibawah ini adalah data kepadatan sepeda motor, mobil pribadi, mobil angkutan umum dan mobil angkutan barang.}

\section{Uji Korelasi}

Pengujian korelasi digunakan untuk mencari hubungan antara dua variabel bebas atau lebih yang secara bersama-sama dihubungkan dengan variabel terikatnya, sehingga diketahui besarnya sumbangan variabel bebas yang menjadi objek penelitian terhadap variabel terikatnya. 


\section{Hipotesis}

$$
\begin{aligned}
\mathrm{H}_{\mathrm{a}}= & \begin{array}{l}
\text { Terdapat pengaruh yang signifikan antara kepadatan sepeda motor, kepadatan } \\
\text { mobil penumpang, kepadatan angkutan umum dan kepadatan angkutan barang }
\end{array} \\
& \text { dengan kebisingan } \\
\mathrm{H}_{\mathrm{O}}= & \begin{array}{l}
\text { Tidak terdapat pengaruh yang signifikan antara kepadatan sepeda motor, } \\
\text { kepadatan mobil penumpang, kepadatan angkutan umum dan kepadatan }
\end{array} \\
& \text { angkutan barang dengan kebisingan } \\
\alpha= & 5,00 \%
\end{aligned}
$$

\section{Analisis Data Statistik}

Pembahasan dengan menggunakan jarak 0,00 $\mathrm{m}$ dengan SLM 1

Pada hasil pengolahan data menggunakan SPSS 17 didapatkan tingkat kebisingan ( $\mathrm{Y})$ dengan kepadatan sepeda motor (SPM/X1), mobil angkutan pribadi (MAP/x2), mobil angkutan umum (MAU/x3 dan mobil angkutan barang $(\mathrm{MAB} / \mathrm{x} 4)$ berdasarkan tingkat kepercayaan 95\%. Berikut disajikan hasil persamaan yang mewakili kondisi jarak $0,00 \mathrm{~m}$ dengan menggunakan SLM 1 adalah : $\mathrm{Y}=$ $87,630-0,036 \times 1-0,207 \times 2+0,008 \times 3+$ $0,092 \times 4$.

(1) Kriteria uji

Hasil pengujian model summary diperoleh nilai $R_{\text {Square }}=0,054$ yang artinya bahwa $\times 1$ berpengaruh sebesar $5,40 \%$ terhadap $Y$.

Hasil uji anova diperoleh nilai $\mathrm{F}_{\text {-Hitung }}=$ 0,617 dengan nilai probabilitas $(\mathrm{sig})=$ 0.653. Dari input data di dapatkan nilai $\mathrm{F}_{- \text {Tabel }}=3.19$ jadi $\mathrm{F}_{- \text {Hitung }}<\mathrm{F}_{\text {-Tabel, }}$ maka $\mathrm{H}_{\mathrm{a}}$ di tolak dan $\mathrm{H}_{\mathrm{o}}$ di terima.

Hasil uji coefficients, kepadatan sepeda motor memiliki nilai konstanta (a) = $87,630,(\mathrm{~b})=-0,036,(\mathrm{c})=-0,207,(\mathrm{~d})=$ 0,08 dan $(\mathrm{e})=0,092$ dan nilai $\mathrm{t}^{-}$-Hitung $=$ 19,950 dan nilai $(\mathrm{sig})=0.000$, dari data di dapatkan nilai ${ }^{-}{ }^{-}$abel $=2.014$, maka $\mathrm{t}-$ Hitung $>\mathrm{t}^{-}$-Tabel, maka $\mathrm{H}_{\mathrm{a}}$ diterima dan $\mathrm{H}_{0}$ di tolak.

(2) Keputusan hipotesis

Hasil statistik uji diatas dapat ditarik hasil keputusan hipotesis mengenai pengaruh kepadatan kendaraan bermotor terhadap kebisingan, bahwa ada pengaruh atau hubungan yang signifikan antara kepadatan kendaraan bermotor terhadap kebisingan yang terjadi di SLM 1 pada hari pertama.

Pembahasan dengan jarak $3,00 \mathrm{~m}$ menggunakan SLM 2

Tingkat kebisingan ( $\mathrm{Y}$ ) dengan kepadatan sepeda motor (SPM/X1), mobil angkutan pribadi (MAP/x2), mobil angkutan umum (MAU/x3 dan mobil angkutan barang $(\mathrm{MAB} / \mathrm{x} 4)$ berdasarkan tingkat kepercayaan 95\%. Berikut disajikan hasil persamaan yang mewakili kondisi jarak 3,00 m dengan menggunakan SLM 2 adalah :

$Y=73,619+0,052 \times 1-0,279 \times 2-$ $0,236 \times 3+0,260 \times 4$.

(1) Kriteria uji

Hasil pengujian model summary diperoleh nilai $R_{\text {Square }}=0.098$ yang artinya bahwa $x 1$ berpengaruh sebesar $9,80 \%$ terhadap $Y$.

Hasil uji anova diperoleh nilai $\mathrm{F}_{\text {-Hitung }}=$ 1.164 dengan nilai probabilitas $(\mathrm{sig})=$ 0.340. Dari input data di dapatkan nilai $\mathrm{F}_{\text {-Tabel }}=3.19$ jadi $\mathrm{F}_{\text {-Hitung }}<\mathrm{F}_{\text {-Tabel }}$, maka $\mathrm{H}_{\mathrm{a}}$ di tolak dan $\mathrm{H}_{\mathrm{o}}$ di terima.

Hasil uji coefficients, kepadatan sepeda motor, memiliki nilai konstanta (a) = 73,619 , (b) $=0,052$, (c) $-0,279$, (d) 0,236, dan (e) 0,260 dan nilai ${ }^{-}-$Hitung $=$ 13,787 dan nilai $(\mathrm{sig})=0.000$, dari data di dapatkan nilai $\mathrm{t}^{-}$-abel $=2.014$, maka $\mathrm{t}$ Hitung $>\mathrm{t}$-Tabel, maka $\mathrm{H}_{\mathrm{a}}$ diterima dan $\mathrm{H}_{\mathrm{o}}$ di tolak.

(2) Keputusan hipotesis

Hasil statistik uji diatas dapat ditarik hasil keputusan hipotesis mengenai pengaruh kepadatan kendaraan bermotor terhadap kebisingan, bahwa ada pengaruh atau hubungan yang signifikan antara kepadatan kendaraan bermotor terhadap kebisingan yang terjadi di SLM 2 pada hari pertama.

Pembahasan dengan jarak $16.00 \mathrm{~m}$ menggunakan SLM 3

Tingkat kebisingan ( $\mathrm{Y})$ dengan kepadatan sepeda motor (SPM/X1), mobil angkutan pribadi (MAP/x2), mobil angkutan umum (MAU/ $\times 3$ dan mobil angkutan barang (MAB/x4) berdasarkan tingkat kepercayaan 95\%. Berikut disajikan hasil persamaan yang mewakili kondisi jarak 16,00 m dengan menggunakan SLM 2 adalah :

$$
\begin{aligned}
& Y=59,170+0,043 \times 1-0,116 \times 2+ \\
& 0,153 \times 3+0,200 \times 4 .
\end{aligned}
$$

(1) Kriteria uji

Hasil pengujian model summary diperoleh nilai $R_{\text {Square }}=0.157$ yang artinya bahwa $\mathrm{x} 1, \mathrm{x} 2, \quad \mathrm{x} 3$ dan $\times 4$ berpengaruh sebesar $15,70 \%$ terhadap Y. 
Hasil uji anova diperoleh nilai $\mathrm{F}_{\text {-Hitung }}=$ 2.009 dengan nilai probabilitas (sig) = 0.102 . Dari input data di dapatkan nilai $\mathrm{F}_{- \text {Tabel }}=3.19$ jadi $\mathrm{F}_{- \text {Hitung }_{\text {}}}<\mathrm{F}_{- \text {Tabel }}$, maka $\mathrm{H}_{\mathrm{a}}$ di tolak dan $\mathrm{H}_{\mathrm{o}}$ di terima.

Hasil uji coefficients, kepadatan sepeda motor, kepadatan mobil angkutan pribadi memiliki nilai konstanta (a) $=$ $59,170,(b)=0,043,(c)=-0,116$ (d) $=$ 0,153 dan $(\mathrm{d})=0,200$ dan nilai $\mathrm{t}_{-}$Hitung $=$ 18,784 dan nilai $(\mathrm{sig})=0.000$, dari data di dapatkan nilai t-Tabel $=2.014$, maka tHitung $>\mathrm{t}^{\mathrm{T}}{ }_{\text {Tabel, }}$, maka $\mathrm{H}_{\mathrm{a}}$ diterima dan $\mathrm{H}_{\mathrm{o}}$ di tolak.

(2) Keputusan hipotesis

Hasil statistik uji diatas dapat ditarik hasil keputusan hipotesis mengenai pengaruh kepadatan kendaraan bermotor terhadap kebisingan, bahwa ada pengaruh atau hubungan yang signifikan antara kepadatan kendaraan bermotor terhadap kebisingan yang terjadi di SLM 3 pada hari pertama.

\section{Analisis Data Statistik}

Pembahasan dengan menggunakan jarak 0,00 $\mathrm{m}$ dengan SLM 1

Tingkat kebisingan (Y) dengan kepadatan sepeda motor (SPM/X1), mobil angkutan pribadi (MAP/x2), mobil angkutan umum (MAU/x3 dan mobil angkutan barang (MAB/ 44$)$ berdasarkan tingkat kepercayaan 95\%. Berikut disajikan hasil persamaan yang mewakili kondisi jarak 0,00 $\mathrm{m}$ dengan menggunakan SLM 1 adalah :

$Y=85,238-0,063 \times 1+0,358 \times 2-$ $0,022 \times 3-0,326 \times 4$.

(1) Kriteria uji

Hasil pengujian model summary diperoleh nilai $R_{\text {Square }}=0.141$ yang artinya bahwa $\mathrm{x} 1, \mathrm{x} 2, \mathrm{x} 3$ dan $\mathrm{x} 4$ berpengaruh sebesar $14,10 \%$ terhadap Y.

Hasil uji anova diperoleh nilai $\mathrm{F}_{\text {-Hitung }}=$ 1.758 dengan nilai probabilitas $(\mathrm{sig})=$ 0.015. Dari input data di dapatkan nilai $\mathrm{F}_{- \text {Tabel }}=3.19$ jadi $\mathrm{F}_{\text {-Hitung }}<\mathrm{F}_{\text {-Tabel }}$, maka $\mathrm{H}_{\mathrm{a}}$ di tolak dan $\mathrm{H}_{0}$ di terima.

Hasil uji coefficients, kepadatan sepeda motor memiliki nilai konstanta (a) $=$ 85,238, (b) $=0.036$, (c) $=0,358,(\mathrm{~d})=$ 0,022 , (e) $=0,328$ dan nilai $\mathrm{t}^{-}$-Hitung $=$ 17,406 dan nilai $(\mathrm{sig})=0.000$, dari data di dapatkan nilai $\mathrm{t}$-Tabel $=2.014$, maka $\mathrm{t}$ Hitung $>\mathrm{t}$-Tabel, maka $\mathrm{H}_{\mathrm{a}}$ diterima dan $\mathrm{H}_{0}$ di tolak.

\section{(2) Keputusan hipotesis}

Hasil statistik uji diatas dapat ditarik hasil keputusan hipotesis mengenai pengaruh kepadatan kendaraan bermotor terhadap kebisingan, bahwa ada pengaruh atau hubungan yang signifikan antara kepadatan kendaraan bermotor terhadap kebisingan yang terjadi di SLM 1 pada hari kedua.

\section{Pembahasan dengan jarak 3,00 m menggunakan SLM 2}

Tingkat kebisingan ( $Y$ ) dengan kepadatan sepeda motor (SPM/X1), mobil angkutan pribadi (MAP/x2), mobil angkutan umum (MAU/ $\times 3$ dan mobil angkutan barang (MAB/ 44$)$ berdasarkan tingkat kepercayaan 95\%. Berikut disajikan hasil persamaan yang mewakili kondisi jarak $3,00 \mathrm{~m}$ dengan menggunakan SLM 2 adalah :

$Y=69,147-0,055 \times 1+0,261 \times 2+$ $0,047 \times 3-0,232 \times 4$.

\section{(1) Kriteria uji}

Hasil pengujian model summary diperoleh nilai $R_{\text {Square }}=0.082$ yang artinya bahwa $x 1$ berpengaruh sebesar $8,20 \%$ terhadap $Y$.

Hasil uji anova diperoleh nilai $\mathrm{F}_{\text {-Hitung }}=$ 0.964 dengan nilai probabilitas $(\mathrm{sig})=$ 0.437 . Dari input data di dapatkan nilai $\mathrm{F}_{\text {-Tabel }}=3.19$ jadi $\mathrm{F}_{\text {-Hitung }}<\mathrm{F}_{\text {-Tabel }}$, maka $\mathrm{H}_{\mathrm{a}}$ di tolak dan $\mathrm{H}_{0}$ di terima.

Hasil uji coefficients, kepadatan sepeda motor barang memiliki nilai konstanta (a) $=69,147$, (b) $=-0,055$, (c) $=0,261$, (d) 0,047 dan (e) $-0,232$ dan nilai $t^{-}$Hitung $=$ 14,312 dan nilai $(\mathrm{sig})=0.000$, dari data di dapatkan nilai $\mathrm{t}^{-}$Tabel $=2.014$, maka $\mathrm{t}$ Hitung $>\mathrm{t}^{-}$Tabel, maka $\mathrm{H}_{\mathrm{a}}$ diterima dan $\mathrm{H}_{\mathrm{o}}$ di tolak.

(2) Keputusan hipotesis

Hasil statistik uji diatas dapat ditarik hasil keputusan hipotesis mengenai pengaruh kepadatan kendaraan bermotor terhadap kebisingan, bahwa ada pengaruh atau hubungan yang signifikan antara kepadatan kendaraan bermotor terhadap kebisingan yang terjadi di SLM 2 pada hari kedua.

Pembahasan dengan jarak $16.00 \mathrm{~m}$ menggunakan SLM 3

Tingkat kebisingan ( $\mathrm{Y})$ dengan kepadatan sepeda motor (SPM/X1), mobil angkutan pribadi (MAP/x2), mobil angkutan umum (MAU/ $\times 3$ dan mobil angkutan barang (MAB/ $\times 4)$ berdasarkan tingkat kepercayaan 95\%. Berikut disajikan hasil 
persamaan yang mewakili kondisi jarak 16,00 m dengan menggunakan SLM 2 adalah :

$Y=60,574+0,010 \times 1+0,099 \times 2+$ $0,073 \times 3-0,068 \times 4$.

\section{(1) Kriteria uji}

Hasil pengujian model summary diperoleh nilai $R_{\text {Square }}=0.072$ yang artinya bahwa $x 1, \quad x 2, \quad x 3$ dan $x 4$ berpengaruh sebesar $7,20 \%$ terhadap Y.

Hasil uji anova diperoleh nilai $\mathrm{F}_{\text {-Hitung }}=$ 0.839 dengan nilai probabilitas (sig) = 0.508 . Dari input data di dapatkan nilai $\mathrm{F}_{\text {-Tabel }}=3.19$ jadi $\mathrm{F}_{\text {-Hitung }}<\mathrm{F}_{\text {-Tabel }}$, maka $\mathrm{H}_{\mathrm{a}}$ di tolak dan $\mathrm{H}_{\mathrm{o}}$ di terima.

Hasil uji coefficients, kepadatan sepeda motor, kepadatan mobil angkutan pribadi, kepadatan mobil angkutan umum memiliki nilai konstanta (a) = 60,574, (b) $=0,010$, (c) $=0,099$, (d) $=$ 0,073, (d) 0,068 dan nilai t $_{-}$Hitung $=27,667$ dan nilai $(\mathrm{sig})=0.000$, dari data di dapatkan nilai ${ }^{-}{ }_{\text {Tabel }}=2.014$, maka ${ }^{-}{ }_{\text {Hitung }}$ $>\mathrm{t}_{-}$Tabel, maka $\mathrm{H}_{\mathrm{a}}$ diterima dan $\mathrm{H}_{\mathrm{o}}$ di tolak.

(2) Keputusan hipotesis

Hasil statistik uji diatas dapat ditarik hasil keputusan hipotesis mengenai pengaruh kepadatan kendaraan bermotor terhadap kebisingan, bahwa ada pengaruh atau hubungan yang signifikan antara kepadatan kendaraan bermotor terhadap kebisingan yang terjadi di SLM 3 pada hari kedua.

\section{Analisis Data Statistik Hari Sabtu}

Pembahasan dengan menggunakan jarak 0,00 $\mathrm{m}$ dengan SLM 1

Tingkat kebisingan (Y) dengan kepadatan sepeda motor (SPM/X1), mobil angkutan pribadi (MAP/x2), mobil angkutan umum (MAU/x3 dan mobil angkutan barang (MAB/x4) berdasarkan tingkat kepercayaan 95\%. Berikut disajikan hasil persamaan yang mewakili kondisi jarak 0,00 $\mathrm{m}$ dengan menggunakan SLM 2 adalah :

$Y=74,729+0,033 \times 1+0,083 \times 2+$ $0,144 \times 3+0,515 \times 4$.

(1) Kriteria uji

Hasil pengujian model summary diperoleh nilai $R_{\text {Square }}=0.180$ yang artinya bahwa $\times 1, x 2, \quad x 3$ dan $\times 4$ berpengaruh sebesar $18,0 \%$ terhadap Y.

Hasil uji anova diperoleh nilai $\mathrm{F}_{\text {-Hitung }}=$ 2.362 dengan nilai probabilitas (sig) = 0.068 . Dari input data di dapatkan nilai
$\mathrm{F}_{\text {-Tabel }}=3.19$ jadi $\mathrm{F}_{\text {-Hitung }}<\mathrm{F}$-Tabel, maka $\mathrm{H}_{\mathrm{a}}$ di tolak dan $\mathrm{H}_{\mathrm{o}}$ di terima.

Hasil uji coefficients, kepadatan sepeda motor, kepadatan mobil angkutan pribadi, kepadatan mobil angkutan umum dan kepadatan mobil angkutan barang memiliki nilai konstanta (a) = 74,729 , (b) $=0,033,(\mathrm{c})=0,083,(\mathrm{~d})=$ 0,144 , (e) $=0,515$ dan nilai $\mathrm{t}^{-}{ }_{\text {Hitung }}=$ 23,263 dan nilai (sig) $=0.000$, dari data di dapatkan nilai $\mathrm{t}^{-}$Tabel $=2.014$, maka $\mathrm{t}-$ Hitung $>\mathrm{t}^{-}{ }_{\text {Tabel}}$, maka $\mathrm{H}_{\mathrm{a}}$ diterima dan $\mathrm{H}_{\mathrm{o}}$ di tolak.

(2) Keputusan hipotesis

Hasil statistik uji diatas dapat ditarik hasil keputusan hipotesis mengenai pengaruh kepadatan kendaraan bermotor terhadap kebisingan, bahwa ada pengaruh atau hubungan yang signifikan antara kepadatan kendaraan bermotor terhadap kebisingan yang terjadi di SLM 1 pada hari ketiga.

Pembahasan dengan jarak 3,00 m menggunakan SLM 2

Tingkat kebisingan (Y) dengan kepadatan sepeda motor (SPM/X1), mobil angkutan pribadi (MAP/x2), mobil angkutan umum (MAU/x3 dan mobil angkutan barang (MAB/x4) berdasarkan tingkat kepercayaan 95\%. Berikut disajikan hasil persamaan yang mewakili kondisi jarak 3,00 $\mathrm{m}$ dengan menggunakan SLM 2 adalah :

$Y=63,080+0,036 \times 1+0,130 \times 2-$ $0,129 \times 3+1,849 \times 4$.

(1) Kriteria uji

Hasil pengujian model summary diperoleh nilai $R_{\text {Square }}=0.237$ yang artinya bahwa $x 1, x 2, \quad x 3$ dan $x 4$ berpengaruh sebesar $23,70 \%$ terhadap Y.

Hasil uji anova diperoleh nilai $\mathrm{F}_{\text {-Hitung }}=$ 3,342 dengan nilai probabilitas ( $\mathrm{sig}$ ) = 0.018 . Dari input data di dapatkan nilai $\mathrm{F}_{- \text {Tabel }}=3.19$ jadi $\mathrm{F}_{- \text {Hitung }}>\mathrm{F}_{- \text {Tabel }}$, maka $\mathrm{H}_{\mathrm{a}}$ di terima dan $\mathrm{H}_{\mathrm{o}}$ di terima. Hasil uji coefficients, kepadatan sepeda motor, kepadatan mobil angkutan pribadi, kepadatan mobil angkutan umum dan kepadatan mobil angkutan barang memiliki nilai konstanta (a) $=63,080$, (b) $=0,036$, (c) $=0,130$, (d) $=-0,129$, (e) $=$ 1,849 dan nilai ${ }^{-}{ }_{-H i t u n g}=20,350$ dan nilai (sig) $=0.000$, dari data di dapatkan nilai $\mathrm{t}^{-}{ }_{\text {Tabel }}=2.014$, maka $\mathrm{t}^{-}{ }_{\text {Hitung }}>\mathrm{t}^{{ }^{-}{ }_{\text {Tabel }} \text {, maka }}$ $\mathrm{H}_{\mathrm{a}}$ diterima dan $\mathrm{H}_{\mathrm{o}}$ di tolak.

(2) Keputusan hipotesis

Hasil statistik uji diatas dapat ditarik hasil keputusan hipotesis mengenai 
pengaruh kepadatan kendaraan bermotor terhadap kebisingan, bahwa ada pengaruh atau hubungan yang signifikan antara kepadatan kendaraan bermotor terhadap kebisingan yang terjadi di SLM 2 pada hari ketiga.

Pembahasan dengan jarak $16.00 \mathrm{~m}$ menggunakan SLM 3

Tingkat kebisingan (Y) dengan kepadatan sepeda motor (SPM/X1), mobil angkutan pribadi (MAP/x2), kepadatan mobil angkutan umum $(\mathrm{MAU} / \mathrm{x} 3)$, mobil angkutan barang $(\mathrm{MAB} / \mathrm{x} 4)$ berdasarkan tingkat kepercayaan 95\%. Berikut disajikan hasil persamaan yang mewakili kondisi jarak 16,00 m dengan menggunakan SLM 3 adalah : $Y=61,492+0,023 \times 1+$ $0,018 \times 2-0,065 \times 3+0,513 \times 4$.

(3) Kriteria uji

Hasil pengujian model summary diperoleh nilai $R_{\text {Square }}=0.213$ yang artinya bahwa $x 1, x 2, \quad x 3$ dan $x 4$ berpengaruh sebesar $21,30 \%$ terhadap Y. Hasil uji anova diperoleh nilai $\mathrm{F}_{-}$-Hitung $=2.913$ dengan nilai probabilitas $(\mathrm{sig})=$ 0.032. Dari input data di dapatkan nilai $\mathrm{F}_{- \text {Tabel }}=3.19$ jadi $\mathrm{F}_{- \text {Hitung }_{\text {Habel }}}>\mathrm{F}_{\text {-Taka }}$ $\mathrm{H}_{\mathrm{a}}$ di terima dan $\mathrm{H}_{\mathrm{o}}$ di terima. Hasil uji coefficients, kepadatan sepeda motor, kepadatan mobil angkutan pribadi, kepadatan mobil angkutan umum dan kepadatan mobil angkutan barang memiliki nilai konstanta $(a)=61,492$, (b) $=0,023,(\mathrm{c})=0,018,(\mathrm{~d})=-0,065,(\mathrm{e})=$ 0,513 dan nilai $\mathrm{t}$-Hitung $=42,786$ dan nilai (sign) $=0.000$, dari data di dapatkan nilai $\mathrm{t}_{\text {-Tabel }}=2.014$, maka $\mathrm{t}_{\text {-Hitung }}>\mathrm{t}^{\mathrm{t}}$-Tabel, maka $\mathrm{H}_{\mathrm{a}}$ diterima dan $\mathrm{H}_{\mathrm{o}}$ di tolak.

(3) Keputusan hipotesis

Hasil statistik uji diatas dapat ditarik hasil keputusan hipotesis mengenai pengaruh kepadatan kendaraan bermotor terhadap kebisingan, bahwa ada pengaruh atau hubungan yang signifikan antara kepadatan kendaraan bermotor terhadap kebisingan yang terjadi di SLM 3 pada hari ketiga.

\section{Analisis Data Statistik}

Pembahasan dengan menggunakan jarak 0,00 $\mathrm{m}$ dengan SLM 1

Pada hasil pengolahan data menggunakan SPSS 17 didapatkan tingkat kebisingan (Y) dengan kepadatan sepeda motor (SPM/X1), kepadatan mobil pribadi (MAP/x2), kepadatan mobil angkutan umum (MAU/x3), kepadatan mobil angkutan barang $(\mathrm{MAB} / \mathrm{x} 4)$ berdasarkan tingkat kepercayaan 95\%. Berikut disajikan hasil persamaan yang mewakili kondisi jarak $0,00 \mathrm{~m}$ dengan menggunakan SLM 1 adalah : $Y=76,233+0,060 \times 1+$ $0,080 \times 2-0,08 \times 3+0,223 \times 4$.

(1) Kriteria uji

Hasil pengujian model summary diperoleh nilai $R_{\text {Square }}=0.063$ yang artinya bahwa $\times 1, \quad x 2, \quad x 3, \quad x 4$ berpengaruh sebesar $6,30 \%$ terhadap Y.

Hasil uji anova diperoleh nilai $\mathrm{F}_{-{ }_{\text {Hitung }}}=$ 0.719 dengan nilai probabilitas (sig) = 0.584. Dari input data di dapatkan nilai $\mathrm{F}_{-}$Tabel $=3.19$ jadi $\mathrm{F}_{- \text {Hitung }_{\text {Tabel }}}<\mathrm{F}_{- \text {Tabel }}$, maka $\mathrm{H}_{\mathrm{a}}$ di tolak dan $\mathrm{H}_{\mathrm{o}}$ di terima.

Hasil uji coefficients, kepadatan sepeda motor, kepadatan mobil angkutan umum memiliki nilai konstanta (a) $=76,233$, (b) $=0,060,(\mathrm{c})=0,080,(\mathrm{~d})=-0,080$, (e) $=$ 0,223 dan nilai ${ }^{-}{ }_{-H i t u n g}=15,325$ dan nilai $(\mathrm{sig})=0.000$, dari data di dapatkan nilai $\mathrm{t}_{-}{ }_{\text {Tabel }}=2.014$, maka $\mathrm{t}_{-}{ }_{\text {Hitung }}>\mathrm{t}^{-}{ }_{\text {Tabel }}$, maka $\mathrm{H}_{\mathrm{a}}$ diterima dan $\mathrm{H}_{\mathrm{o}}$ di tolak.

(2) Keputusan hipotesis

Hasil statistik uji diatas dapat ditarik hasil keputusan hipotesis mengenai pengaruh kepadatan kendaraan bermotor terhadap kebisingan, bahwa ada pengaruh atau hubungan yang signifikan antara kepadatan kendaraan bermotor terhadap kebisingan yang terjadi di SLM 1 pada hari keempat.

Pembahasan dengan jarak 3,00 m menggunakan SLM 2

Tingkat kebisingan (Y) dengan kepadatan sepeda motor (SPM/X1), kepadatan mobil angkutan pribadi (MAP/x2) kepadatan mobil angkutan umum (MAU/x3) dan kepadatan mobil angkutan barang (MAB/x4) berdasarkan tingkat kepercayaan 95\%. Berikut disajikan hasil persamaan yang mewakili kondisi jarak 3,00 m dengan menggunakan SLM 2 adalah : $\mathrm{Y}=$ $66,827+0,028 \times 1+0,184 \times 2-0,003 \times 3-$ $0,101 \times 4$.

(1) Kriteria uji

Hasil pengujian model summary diperoleh nilai $R_{\text {Square }}=0,067$ yang artinya bahwa x1, x2, x3 dan x4 hanya berpengaruh sebesar $6,70 \%$ terhadap Y.

Hasil uji anova diperoleh nilai $\mathrm{F}_{\text {-Hitung }}=$ 0.776 dengan nilai probabilitas (sig) = 0.547. Dari input data di dapatkan nilai $\mathrm{F}_{\text {-Tabel }}=3.19$ jadi $\mathrm{F}_{\text {-Hitung }}<\mathrm{F}_{\text {-Tabel }}$, maka $\mathrm{H}_{\mathrm{a}}$ di tolak dan $\mathrm{H}_{0}$ di terima.

Hasil uji coefficients, kepadatan sepeda motor, kepadatan mobil angkutan 
pribadi, kepadatan mobil angkutan umum dan kepadatan mobil angkutan barang memiliki nilai konstanta (a) = 66,827, (b) =0,028, (c) =0,184, (d) = 0,003 , (e) $=-101$ dan nilai t $_{\text {-Hitung }}=$ 14,425 dan nilai $(\mathrm{sig})=0.000$, dari data di dapatkan nilai t- ${ }^{-}$abel $=2.014$, maka tHitung $>{ }^{t}{ }_{-}$Tabel, maka $\mathrm{H}_{\mathrm{a}}$ diterima dan $\mathrm{H}_{\mathrm{o}}$ di tolak.

(2) Keputusan hipotesis

Hasil statistik uji diatas dapat ditarik hasil keputusan hipotesis mengenai pengaruh kepadatan kendaraan bermotor terhadap kebisingan, bahwa ada pengaruh atau hubungan yang signifikan antara kepadatan kendaraan bermotor terhadap kebisingan yang terjadi di SLM 2 pada hari keempat.

Pembahasan dengan jarak $16.00 \mathrm{~m}$ menggunakan SLM 3

Tingkat kebisingan $(Y)$ dengan kepadatan sepeda motor (SPM/X1), kepadatan mobil angkutan pribadi (MAP/x2), kepadatan mobil angkutan umum (MAU/x3). Kepadatan mobil angkutan barang (MAB/x4) berdasarkan tingkat kepercayaan 95\%. Berikut disajikan hasil persamaan yang mewakili kondisi jarak 16,00 m dengan menggunakan SLM 3 adalah : $Y=$ $61,101+0,054 \times 1-0,0675 \times 2+0,052 \times 3$ $-0,286 \times 4$.

(1) Kriteria uji

Hasil pengujian model summary diperoleh nilai $R_{\text {Square }}=0.217$ yang artinya bahwa $\times 1, \quad x 2, \quad x 3, \quad \times 4$ berpengaruh sebesar $21,70 \%$ terhadap Y.

Hasil uji anova diperoleh nilai $\mathrm{F}_{\text {-Hitung }}=$ 2.977 dengan nilai probabilitas (sig) = 0.030. Dari input data di dapatkan nilai $\mathrm{F}_{\text {-Tabel }}=3.19$ jadi $\mathrm{F}_{\text {-Hitung }}<\mathrm{F}_{\text {-Tabel }}$, maka $\mathrm{H}_{\mathrm{a}}$ di tolak dan $\mathrm{H}_{\mathrm{o}}$ di terima.

Hasil uji coefficients, kepadatan sepeda motor, kepadatan mobil angkutan pribadi, kepadatan mobil angkutan umum dan kepadatan mobil angkutan barang memiliki nilai konstanta (a) = 61,1701, (b) =0,054, (c) = -0,067, (d) = 0,566, (e) $=-0,286$ dan nilai $\mathrm{t}_{-}$Hitung $=$ 22,862 dan nilai (sign) $=0.000$, dari data di dapatkan nilai $\mathrm{t}^{-}$-Tabel $=2.014$, maka $\mathrm{t}_{-}$Hitung $>\mathrm{t}^{\mathrm{-}}$ Tabel, maka $\mathrm{H}_{\mathrm{a}}$ diterima dan $\mathrm{H}_{\mathrm{o}}$ di tolak.

(2) Keputusan hipotesis

Hasil statistik uji diatas dapat ditarik hasil keputusan hipotesis mengenai pengaruh kepadatan kendaraan bermotor terhadap kebisingan, bahwa ada pengaruh atau hubungan yang signifikan antara kepadatan kendaraan bermotor terhadap kebisingan yang terjadi di SLM 3 pada hari keempat.

\section{KESIMPULAN}

Kepadatan sepeda motor, mobil angkutan pribadi, mobil angkutan umum dan mobil angkutan barang memiliki pengaruh yang signifikan terhadap kebisingan, dari semua perhitungan analisis didapatkan persamaan terbesar pada penelitian hari ketiga titik kedua (Sound Level Meter 2), dengan kontribusi sebesar 23,70\%. Didapatkan perhitungan di bawah ini, $Y=63,080+0,036 \times 1+0,139 \times 2-$ $0,129 \times 3+0,943 \times 4$.

Maksudnya jika tidak ada penurunan kepadatan sepeda motor maka tingkat kebisingan di SLM 2 adalah sebesar 63,080 $\mathrm{dB}_{\mathrm{A}}$. Apabila terjadi penambahan peningkatan kepadatan sepeda motor sebesar $+1,118$ kend./jam dan penurunan kepadatan mobil angkutan umum -0,129 kend./jam.

Kepadatan sepeda motor, mobil pribadi, mobil angkutan umum dan mobil angkutan barang juga memiliki pengaruh yang signifikan terhadap kebisingan didapatkan persamaan kedua terbesar terbesar pada penelitian hari ke empat dititik ke tiga (Sound Level Meter 3) dengan kontribusi sebesar 21,70\%. Didapatkan perhitungan persamaan di bawah ini, $Y=61,101+0,054 \times 1-0,067 \times 2+0,052 \times 3$ $-0,286 \times 4$.

Maksud dari persamaan diatas adalah jika ada peningkatan kepadatan sepeda motor, mobil angkutan umum maka kebisingan di SLM 3 adalah sebesar $61,101 \quad \mathrm{~dB}_{\mathrm{A}}$. Jadi untuk penurunan kepadatan angkutan pribadi dan kepadatan mobil angkutan barang sebesar 0,353 kend./jam dan maka akan terjadi peningkatan kepadatan sepeda motor, peningkatan mobil angkutan umum sebesar 0,106 kend./jam.

\section{DAFTAR PUSTAKA}

Buchari, Kebisingan Industri dan Hearing Conservation program, 2007 USU resposiroty, 2007.

Departemen Pekerjaan Umum Direktorat Jenderal Bina Marga, , Pebruari 1997 Manual Kapasitas Jalan Indonesia (MKJI).

Hidayati, Nurul, Pengaruh Arus Lalu Lintas terhadap kebisingan (Studi Kasus Beberapa Zona Pendidikan Di Surakarta). Surakarta, 2007.

Linasari P. Bangun, dkk, Kebisingan Lalu Lintas Dan Hubungannya Dengan 
Tingkat Ketergangguan Masyarakat, Fakultas Teknik Sipil dan Lingkungan ITB, Bandung.

Menteri Negara Lingkungan Hidup, 1996, Baku Tingkat Kebisingan, Surat Keputusan Menteri Lingkungan Hidup Nomor : Kep48/MENLH/1996/25 November 1996, Jakarta.

Syaiful, Syaiful, 2005, Analisis Kebisingan Arus Lalu Lintas Dan Geometri Jalan Di Kawasan Simpang Lima Kota Semarang. Masters thesis, program Pascasarjana Universitas Diponegoro. Diponegoro University, Semarang: INSTITUTIONAL REPOSITORY.

Syaiful (2012), STUDI KASUS TENTANG TINGKAT KEBISINGAN YANG DITIMBULKAN KENDARAAN BERMOTOR DI BOGOR (Kajian di Depan Rumah Sakit Azra Jalan Pajajaran Kota Bogor), ISSN 23024240, Vol 1, No 1 (2012).

http://ejournal.uika-

bogor.ac.id/index.php/ASTONJADRO/ar ticle/view/785

Syaiful (2015). Tingkat Resistensi Polusi Suara di Depan RSIA Sentosa Bogor, Jurnal Astonjadro, ISSN 2302-4240, Vol 4, No 2 (2015)

http://ejournal.uika-

bogor.ac.id/index.php/ASTONJADRO/ar ticle/view/828

Syaiful, S., \& Elvira, Y. (2017). Case Study On Use Area Parking At New Market City Shopping Center Bogor. IJTI (International Journal Of Transportation And Infrastructure), 1(1), 34-40. Retrieved from http://jurnal.narotama.ac.id/index.php/ijti/ article/view/330

Syaiful (2017) Engineering model of traffic and transportation safety with pattern of cooperation between sustainable region in Bogor, MATEC Web Conf. 13807008 DOI: $10.1051 /$ matecconf/201713807008 https://doi.org/10.1051/matecconf/20171 3807008

Syaiful Syaiful, Mikhael Yuliantino (2017) THE STUDY OF LAND PARKING MALL BOGOR INDAH PLAZA Proceedings of the Conference on Global Research on Sustainable Transport (GROST 2017) ISSN: 2352-5401, volume: 147 ISBN
978-94-6252-449-1 doi:10.2991/grost17.2018 .25 p. $286-303$

https://www.atlantis-

press.com/proceedings/grost$\underline{17 / 25889389}$

Syaiful Syaiful, Zainal Abidin (2017) Pengaruh Volume Lalu Lintas Terhadap Kebisingan Yang Ditimbulkan Kendaraan Bermotor, Prosiding Simposium II - UNIID 2017, e-ISBN 978979-587-734-9 Vol 2 (2017) p. 229-234 http://conference.unsri.ac.id/index.php/u niid/article/view/609

Tamin Z Ofyar., Perencanaan dan pemodelan transfortasi, edisi ke dua, 2000, Penerbit ITB Bandung.

Warpani P Suwardjoko., Pengelolaan Lalu lintas dan Angkutan Jalan, tahun 2002, penerbit ITB Bandung. 